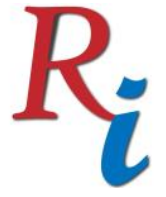

Asia Proceedings of Social Sciences

(APSS)

www.readersinsight.net/APSS

\title{
FACTORS INFLUENCING EMPLOYABILITY OF CHINESE GRADUATES IN MALAYSIA UPON RETURNING TO CHINA \\ Tee Poh Kiong*
}

Asia Pacific University of Technology and Innovation

Malaysia

\section{Eaw Hooi Cheng}

UCSI University

Malaysia

\section{Oh Siew Pei}

UCSI University

Malaysia

\section{Han Kok Siew}

Asia Pacific University of Technology and Innovation

Malaysia

*Corrosponding author's Email: seantee@live.com, poh.kiong@apu.edu.my

Author's Biography

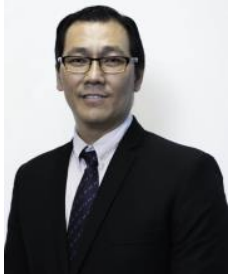

Mr Tee Poh Kiong is a Senior Lecturer in School of Business and Management at Asia Pacific University in Kuala Lumpur, Malaysia. He is now pursuing his PhD in Management from University Tunku Abdul Rahman. In year 1997, he started his professional career as Marketing Manager attached with a Japanese company for 8 years. Since 2005, he started working as a Lecturer and Senior Lecturer in various higher education institutions. He has been actively involved in research and publication. His research interests include employability, career management, organizational behavior, consumer behavior and brand management.

Peer-review under responsibility of $3^{\text {rd }}$ Asia International Multidisciplanry Conference 2019 editorial board (http://www.utm.my/asia/our-team/) (C) 2019 Published by Readers Insight Publisher, lat 306 Savoy Residencia, Block 3 F11/1,44000 Islamabad. Pakistan, info@ readersinsight.net This is an open access article under the CC BY-NC-ND license (http://creativecommons.org/licenses/by-nc-nd/4.0/). 


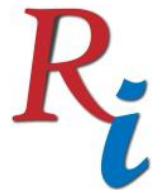

\section{Asia Proceedings of Social Sciences \\ (APSS) \\ www.readersinsight.net/APSS}

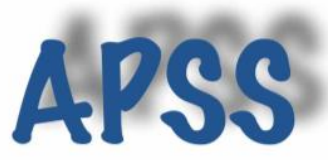

\section{Rese a r ch H i g h I igh t s}

This study indicates important factors in related to Chinese international students who graduated from Malaysia have better 'employability' upon returning to China employment market. Total survey of 160 samples collected from the target group, the Chinese graduates who study in Malaysia and now working in China. The direct model result found that educational and learning activities (H1) and soft skills (H2) have a significant impact on graduate's employability. Moreover, the findings also found the mediation role of graduate's English proficiency scored at 0.1595 (H3) and 0.1293 (H4) between educational and learning activities, soft skills and employability. The findings enable education service providers and policy-makers identify more competitive variables in enhancing graduate employability in China market. Additionally, the result of this study also justified the important of English proficiency toward the employability of Chinese graduates in China.

\section{Research Objectives}

The rising number of returnees graduated abroad has created a fierce competition among Chinese graduates upon retuning to China. This paper aims to investigate the factors (education and learning activities and soft-skills) influencing the employability of Chinese graduates from Malaysia upon returning to China employment market. Particularly, with regard to cognitive and psychological dimensions, English proficiency might directly and indirectly impact international students' employability. McKenzie \& Schweitzer (2001) and Yang et al (2006) indicated that English proficiency found to be a main factor influencing fresh graduate selfefficicacy and self confidence level in handling their work and learning a new process on their work to imporve their soft skills level. Hence, this paper further investigates the mediating (indirect) effect of English proficiency in order to justify the important of language (English) proficiency on employability in China labour market.

\section{Methodology}

Quantitative research approach through a cross-sectional study using questionnaire to collect direct data. Finch, Hamilton, Baldwin, \& Zehnar (2013) indicated study of employability are appropriated to conducted in survey method. Total 160 samples are collected based on convenience sampling method. According to Sekaran \& Bougie (2010) samples between 30 to 500 are sufficient use for mutiple regression analysis. The data was collected through e-mail to the China graduates or alumnus who graduated from Malaysia and currently working in China. The survey questions were strcutured based on five-point Likert scale for all respective variables: (1) Strongly Disagree, (2) Disagree, (3) Neutral, (4) Agree and (5) Strongly Agree. All the measures for the variables used in this study are adapated from the past literature. Table 1 shows the structure of the questionnaire used in this study:

Table 1. Questionnaire section

\begin{tabular}{ccc}
\hline Section & Variable & Adapted From \\
\hline 1 & Demographic & Profile of the respondent \\
2 & Independent variable & Educational and learning activities (Ishengoma \& Vaaland, 2016) \\
3 & Independent variable & Soft skill (Nabi, 2003) \\
4 & Mediating variable & English language proficiency (Singh \& Singh, 2008) \\
5 & Dependent variable & Employability (Xanou, 2016) \\
\hline
\end{tabular}




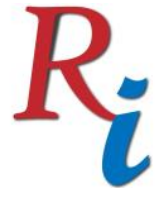

\section{Asia Proceedings of Social Sciences \\ (APSS) \\ www.readersinsight.net/APSS}

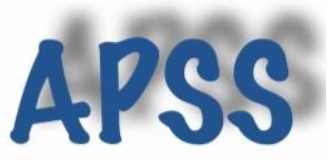

\section{Results}

Average variance extracted (AVE) had scored more than 0.5 and composite reliability and Cronbach's alpha are shown greater than 0.7 which have achieved the data validiity and reliability. The inter-correlation coefficients showed the score for all the variables are smaller than 0.90 , proof that there had no significant multicollinearity among all the indicators.

Direct model measurement indicated that educational and learning activities $(\beta=.6970$, $\mathrm{t}=10.9533, \mathrm{p}<.001)$ and soft skills $(\beta=.7710, \mathrm{t}=12.0788, \mathrm{p}<.001)$ were found significantly impact on employability with t-statistics greater than 1.96 respectively. The result also indicated that education and learning activities has 0.486 impact factor, whereas soft skill has 0.595 impact factor toward employability. In addition, results in mediation model indicated a positive partial mediating effects of English language proficiency (mediating effect $=0.1595$ ) occurs in the relationship between educational and learning activities and perceived employability. Additionally, English language proficiency (mediating effect=0.1293) also mediates the relationship between soft-skills and perceived employability of Chinese graduates from Malaysia in China. The results justify that English proficiency is considered an important criteria towards graduates' employability

\section{Findings}

The following table summarised all the findings of this study and justify the relationship between all the constructs in this study.

H1: There is a relationship between educational and learning activities and perceived employability of Chinese Significant $R^{2}=.4868$ graduates from Malaysia in China.

H2: There is a relationship between graduate's soft skills and perceived employability of Chinese graduates from Significant $R^{2}=.5945$ Malaysia in China.

H3: Graduate's English proficiency mediates the relationship between educational and learning activities and perceived employability of Chinese graduates from Malaysia in China.

H4: Graduate's English proficiency mediates the relationship between soft-skills and perceived employability Significant of Chinese graduates from Malaysia in China.

Positive and significant Significant partial mediating effect (Mediating effect $=.1595$ )

Positive and significant partial mediating effect (Mediating effect $=.1293$ )

\section{Acknowledgement}

The authors would like to express their great appreciation to our colleagues for their professional comments and constructive ideas regarding this manuscript. Furthermore, we would like to thank the anonymous reviewers and the editor for the valuable comments.

\section{References}

Finch, D. J., Hamilton, L. K., Baldwin, R., \& Zehnar, M. (2013). An exploratory study of factors affecting undergraduate employability. Education + Training, 55(7), 681-704.

Ishengoma, E., \& Vaaland, T. I. (2016). Can university-industry linkages stimulate student employability? Education + Training, 58(1), 18-44.

McKenzie, K., \& Schweitzer, R. (2001). Who succeeds at university? Factors predicting academic performance in the first year Australian university students. Higher Education Research and Development, 20, 2133.

Nabi, G. R. (2003). Graduate employment and underemployment: opportunity for skill use and career experiences amongst recent business graduates. Education + Training, 45(7), 371-382. 


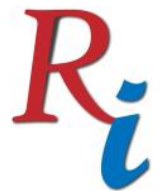

\section{Asia Proceedings of Social Sciences}

(APSS)

www.readersinsight.net/APSS

Sekaran, U., \& Bougie, R. (2010). Research method for business: A skill building approach (5th ed.). New Jersey: John Wiley and Sons.

Singh, G. K. G., \& Singh, S. K. G. (2008). Malaysian graduates' employability skills. UNITAR e-Journal, 4(1), $15-45$.

Yang, P. J., Noels, K. A., \& Saumure, K. D. (2006). Multiple routes to cross-cultural adaptation for international students: Mapping the paths between self-construal, English language confidence, and adjustment. International Journal of Intercultural Relations, 30, 487-506.

Xanou, J. (2016). The impact of perceived employability on the relationship between temporary employment and work related wellbeing. (Master Thesis), Tilburg University. 